Atmos. Chem. Phys., 8, 73-82, 2008

www.atmos-chem-phys.net/8/73/2008/

(C) Author(s) 2008. This work is licensed

under a Creative Commons License.

\title{
Growth rates of stratospheric HCFC-22
}

\author{
D. P. Moore and J. J. Remedios \\ EOS, Space Research Centre, Department of Physics and Astronomy, University of Leicester, Leicester, LE1 7RH, UK
}

Received: 30 May 2007 - Published in Atmos. Chem. Phys. Discuss.: 23 July 2007

Revised: 22 November 2007 - Accepted: 10 December 2007 - Published: 14 January 2008

\begin{abstract}
The Michelson Interferometer for Passive Atmospheric Sounding onboard ENVISAT (MIPAS-E) offers the opportunity to detect and spectrally resolve many atmospheric minor constituents affecting atmospheric chemistry. In this paper, we describe an algorithm produced to retrieve HCFC-22 profiles from MIPAS-E measurements made in 2003 and present results from this scheme between 300 and $50 \mathrm{mb}$. By comparison with ATMOS (AT-3) version 3 data, we find a mean Northern Hemisphere midlatitude $\left(20-50^{\circ} \mathrm{N}\right) \mathrm{HCFC}-22$ growth rate between 1994 and 2003 of $5.4 \pm 0.7 \mathrm{pptv} / \mathrm{yr}$ in the lower stratosphere (LS) and a mean LS Southern Hemisphere growth rate $\left(60-80^{\circ} \mathrm{S}\right)$ of $6.0 \pm 0.7 \mathrm{pptv} / \mathrm{yr}$ in the same period. We test the feasibility of using a global data set to estimate the chemical lifetime of HCFC -22 in the LS and we derive this for two regions: 20 $50^{\circ} \mathrm{N}\left(246 \pm 38\right.$ years) and $60-80^{\circ} \mathrm{S}$ (274 \pm 34 years). From these data we note a global LS lifetime of $260 \pm 25$ years, significantly longer than previous estimates.
\end{abstract}

\section{Introduction}

In the early 1970s it was discovered that chlorofluorocarbons (CFCs), including CFC-11 $\left(\mathrm{CCl}_{3} \mathrm{~F}\right)$ and $\mathrm{CFC}-12\left(\mathrm{CCl}_{2} \mathrm{~F}_{2}\right)$, initiate strong stratospheric ozone depletion (Molina and Rowland, 1974). The CFCs are chemically inert in the troposphere, destruction in the stratosphere can occur either by photolysis or by reaction with $\mathrm{O}\left({ }^{1} \mathrm{D}\right)$ (Brasseur, 1999). All of the chlorine contained in these compounds is released in the stratosphere and then initiates ozone depletion through a number of catalytic cycles. Hydrogenated CFCs (HCFCs) were seen as a viable alternative to CFCs due to their similar thermodynamic properties and, importantly, their primary sink which is in the troposphere through oxidation with the

Correspondence to: D. P. Moore

(dpm9@le.ac.uk) hydroxyl radical $(\mathrm{OH})$. This ultimately results in a lower flux of chlorine to the stratosphere (WMO, 1995) and therefore a lower impact on the ozone layer. Although the ozone depletion potential of $\mathrm{HCFC}-22\left(\mathrm{CHF}_{2} \mathrm{Cl}\right)$ is 20 times lower than that for CFC-12 (WMO, 2007), it was decided that the production of all HCFCs also needed to be regulated. In 1990, the Montreal Protocol (UNEP, 1996) set limits on HCFC production, with total phaseout planned in developed countries by 2030 and developing countries by 2040 .

The major issue with the production and use of HCFC22 is that it is an efficient greenhouse gas; it is 1700 times stronger as a greenhouse gas than an equivalent volume mixing ratio (vmr) of $\mathrm{CO}_{2}$. The radiative forcing of climate due to HCFC-22 is currently third amongst all halocarbons at $0.208 \mathrm{Wm}^{-2} \mathrm{ppbv}^{-1}$ (Sihra et al., 2001), behind only CFC$12\left(0.32 \mathrm{Wm}^{-2} \mathrm{ppbv}^{-1}\right)$ and CFC-11 $\left(0.24 \mathrm{Wm}^{-2} \mathrm{ppbv}^{-1}\right)$ in importance.

In January 2004, the global surface mean of HCFC-22 was 160 pptv (derived from NOAA Earth System Research Laboratory (ESRL) flask measurements) and increasing steadily at 5 pptv/yr. Montzka and Fraser (2003) conclude that global emissions of HCFC-22 rose steadily over the period 1975 to 2000, while those of other HCFCs such as HCFC-141b and HCFC-142b started increasing quickly in the early 1990s and then began to decrease after 2000. According to data provided by AFEAS (2003), the estimated surface emission of HCFC-22 increased from $2.1 \times 10^{5}$ metric tonnes in 1998 to $2.4 \times 10^{5}$ metric tonnes in 2002 . Conversely, the estimated production rate of HCFC-22 over the same period actually decreased by $8 \times 10^{4}$ metric tonnes, from $2.7 \times 10^{5}$ metric tonnes in 1998 to $1.9 \times 10^{5}$ metric tonnes in 2002 . Tropospheric measurements made between 1987 and 2002 by Rinsland et al. (2005b) using a ground-based Michelson Interferometer at Kitt Peak in southern Arizona $\left(31.9^{\circ} \mathrm{N}\right.$ $111.6^{\circ} \mathrm{W}, 2.09 \mathrm{~km}$ altitude) show a linear rise in HCFC22 concentrations of $5.66 \pm 0.15 \mathrm{pptv} / \mathrm{yr}$, or $6.47 \pm 0.17 \% / \mathrm{yr}$ over the whole of that period. The tropospheric lifetime

Published by Copernicus Publications on behalf of the European Geosciences Union. 
of HCFC-22 has been determined from a number of studies (e.g. O'Doherty et al., 2004; Montzka and Fraser, 2003; Miller et al., 1998) and has been estimated to vary between 9 and 13 years.

The decadel lifetime of HCFC-22 in the troposphere allows troposphere-stratosphere mixing to occur and previous measurements made at Aire sur l'Adour, France, between 1982 and 1999 (Fabian and Borchers, 2001) showed the presence of HCFC-22 in the stratosphere with a mixing ratio that increased by $78 \mathrm{pptv}$ at $20 \mathrm{~km}$, during the 1982 to 1999 period. Over the coming decade, atmospheric vmrs of HCFC-22 are expected to increase further as escape from refrigeration and air conditioning units continues. If Montreal Protocol targets are met, decay is then expected to occur, first detectable in the troposphere and then in the stratosphere. Hence, it is currently important to continue monitoring stratospheric concentrations of HCFC-22.

In this paper, we describe an algorithm produced to retrieve HCFC-22 profiles from measurements made by the Michelson Interferometer for Passive Atmospheric Sounding onboard ENVISAT (MIPAS-E), and present results from this scheme. We compare our results from 2003 to measurements made from ATMOS in 1994 in the Northern Hemisphere mid-latitudes $\left(20\right.$ to $\left.50^{\circ} \mathrm{N}\right)$ in a manner similar to Rinsland et al. (2005a), and then extend our analyses to the Southern Hemisphere Polar region $\left(60\right.$ to $\left.80^{\circ} \mathrm{S}\right)$. From this we produce estimates of both the mid-latitude and Southern Hemisphere polar trends of HCFC-22 between 1994 and 2003. Finally, we calculate the lower stratospheric chemical lifetime of HCFC-22 at two locations; 20 to $50^{\circ} \mathrm{N}$ and 60 to $80^{\circ} \mathrm{S}$.

\section{MIPAS-E measurements of HCFC-22}

The MIPAS-E instrument was successfully launched onboard the ENVIronmental SATellite (ENVISAT) in March 2002 as part of an ambitious and innovative payload. The ENVISAT is in a polar orbit at an altitude of $800 \mathrm{~km}$, with an orbital period of about $100 \mathrm{~min}$ and a reference orbit repeat cycle of 35 days. The MIPAS-E (Fischer and Oelhaf, 1996; Fischer et al., 2007) is a Fourier Transform Spectrometer that provides continual limb emission measurements in the mid infrared over the range $685-2410 \mathrm{~cm}^{-1}(14.6-4.15 \mu \mathrm{m})$ at an unapodized resolution of $0.025 \mathrm{~cm}^{-1}$. The instrument's field of view is approximately $3 \times 30 \times 400 \mathrm{~km}$ and one complete limb sequence of measurements in nominal mode consists of 17 spectra with tangent altitudes at $68 \mathrm{~km}, 60 \mathrm{~km}, 52 \mathrm{~km}$, $47 \mathrm{~km}, 42 \mathrm{~km}$ and continuing downwards to $6 \mathrm{~km}$ in $3 \mathrm{~km}$ intervals.

\subsection{Retrieval set-up}

One of the main vibration-rotation transition features of HCFC-22 is the $2 v_{2}$ band with an intense and very narrow Q-branch centred at $829.05 \mathrm{~cm}^{-1}$ (Varanasi, 1992). The fea- ture has been previously used to successfully retrieve HCFC22 volume mixing ratios (vmrs) from measurements made by the ATMOS instrument (e.g. Rinsland et al., 2005a).

The Oxford Reference Forward Model (RFM) was employed in order to model the observed spectra measured by MIPAS-E. The RFM is a line-by-line radiative transfer model, derived from the Genln 2 model (Edwards, 1992), with the ability to simulate infra-red spectra given the instrument lineshape, field-of-view, spectroscopic parameters and atmospheric composition profiles (see http://www.atm.ox.ac. $\mathrm{uk} / \mathrm{RFM} /$ for further details).

Figure 1 shows the contribution of HCFC-22 to the limb radiance measured by MIPAS-E between 828.95 and $829.15 \mathrm{~cm}^{-1}$ at 12 and $21 \mathrm{~km}$ in the mid-latitudes $\left(20\right.$ to $\left.65^{\circ}\right)$, as calculated using the line-by-line Oxford reference forward model (RFM). Profiles for pressure, temperature, HCFC22 and all the interfering gases over the range were taken from the version 3.1 mid-latitude day reference atmospheres of Remedios et al. (2007). Firstly, reference atmospheric limb emission spectra were calculated at a spectral resolution of $0.025 \mathrm{~cm}^{-1}$ at 12 and $21 \mathrm{~km}$ including HCFC-22 and all other emitters in the region. To remove saturation effects, a second spectrum was calculated at the same resolution with all gases except HCFC-22. Differencing these two spectra leaves the radiance attributable to HCFC-22 only. The same method was used to determine the radiance contribution for each of the other interfering gases; the major contaminants include CFC-11, $\mathrm{C}_{2} \mathrm{H}_{6}, \mathrm{ClONO}_{2}, \mathrm{CO}_{2}, \mathrm{H}_{2} \mathrm{O}$ and $\mathrm{O}_{3}$. The HCFC-22 signal is expected to exceed the MIPAS-E noise equivalent spectral radiance (NESR) between 828.95 to $829.15 \mathrm{~cm}^{-1}$ at $12 \mathrm{~km}$. At $21 \mathrm{~km}$, however, the observed inflight MIPAS-E NESR of $20-30 \mathrm{nW} /\left(\mathrm{cm}^{2} \mathrm{sr} \mathrm{cm}^{-1}\right.$ ) (Kleinert et al., 2007) is important with only the peak of the $829.05 \mathrm{~cm}^{-1}$ Q-branch visible above this NESR level. As such, the $829.05 \mathrm{~cm}^{-1}$ Q-branch may still be visible in $21 \mathrm{~km}$ spectra and provide some useful HCFC-22 concentration information. We see that the 828.95 to $829.15 \mathrm{~cm}^{-1}$ region is therefore most suitable for retrievals from the upper troposphere and lowermost stratosphere and is used in this study. The microwindow used for total particle extinction retrieval is $832.3-834.4 \mathrm{~cm}^{-1}$, based on the findings of Spang et al. (2004), who characterise this region as being particularly sensitive to aerosol and cloud emissions.

The retrievals of HCFC-22 vmrs from MIPAS-E data have been achieved using the OPtimal Estimation Retrieval Algorithm (OPERA), designed to invert MIPAS-E spectral measurements which is described in more detail in Moore (2005) and also Moore et al. (2006). In essence, the scheme uses the optimal estimation approach (Rodgers, 2000) to determine the most probable solution consistent with both the measurements and the a priori information.

Consider the set-up of the MIPAS-E, which makes $m$ radiance measurements at different limb altitudes. A set of $n$ parameters (the state vector $\boldsymbol{x}$ ) are determined from this set of measurements $(\boldsymbol{y})$. The aim of the retrieval is to gain as much 
information about $\boldsymbol{x}$ given $\boldsymbol{y}$. The associated random error of the measurements, the measurement noise, is denoted by the vector $\boldsymbol{\epsilon}$.

The state vector and the measurement vector are related by a forward model, $\boldsymbol{F}(\boldsymbol{x})$, which attempts to approximate the atmospheric physics involved. Assuming a perfect model:

$\boldsymbol{y}=\boldsymbol{F}(\boldsymbol{x})+\boldsymbol{\epsilon}$

The forward model incorporates knowledge of how the instrument works, coupled with how the measured quantity from the instrument (radiance for MIPAS-E) is related to the desired quantity (for example volume mixing ratios).

The remote sensing retrieval problem is non-linear and so simplifying assumptions are made to reduce the problem to a linear one. Optimal estimation (Rodgers, 2000) provides a linearized form for an estimate of $\hat{\boldsymbol{x}}$ (the atmospheric profile) that is based on a prior estimate $\boldsymbol{x}_{\boldsymbol{a}}$ of the state and the set of measurements from the instrument:

$\hat{\boldsymbol{x}}=\mathbf{G y}+\left(\mathbf{I}_{n}-\mathbf{G K}\right) \boldsymbol{x}_{\boldsymbol{a}}$

where $\mathbf{K}$ is the Jacobian matrix $\left(\mathrm{K}_{i, j}=\partial \mathrm{y}_{i} / \partial \mathrm{x}_{j}\right)$ and $\mathbf{G}$ is the gain matrix given by:

$\mathbf{G}=\mathbf{S}_{a} \mathbf{K}^{T}\left(\mathbf{S}_{y}+\mathbf{K} \mathbf{S}_{a} \mathbf{K}^{T}\right)^{-1}$

$\mathbf{S}_{a}$ is the covariance of $\boldsymbol{x}_{\boldsymbol{a}}$ about the exact state, and $\mathbf{S}_{y}$ the covariance of $\mathbf{y}$ about the perfect measurements that would arise from the exact state. For $\mathbf{S}_{a}$, the off-diagonal elements were determined by a first order auto-regressive model with a vertical correlation length of $6 \mathrm{~km}$. With uncorrelated a priori data (off-diagonal elements of $\mathbf{S}_{a}$ set to zero) retrieval oscillations occurred. Introducing a correlation length of $6 \mathrm{~km}$ efficiently reduces these oscillations with the trade-off of reducing the vertical resolution of the observations from $3 \mathrm{~km}$ to around $4 \mathrm{~km}$. The off-diagonal elements of $\mathbf{S}_{y}$ were set to zero (assuming no noise correlation between different altitudes).

If the problem is not too non-linear, then the LevenbergMarquardt iteration technique can be used to find the best estimate of the state, $\hat{\boldsymbol{x}}$. The technique is similar to GaussNewton iteration but with the addition of an extra constant term, $\gamma$, which aids convergence. The iteration equation is written as:

$$
\begin{aligned}
\boldsymbol{x}_{\boldsymbol{i}+\mathbf{1}}= & \boldsymbol{x}_{\boldsymbol{i}}+\left[(1+\gamma) \mathbf{S}_{a}^{-1}+\mathbf{K}_{i}^{T} \mathbf{S}_{y}^{-1} \mathbf{K}_{i}\right]^{-1} \\
& \left\{\mathbf{K}_{i}^{T} \mathbf{S}_{y}^{-1}\left[\boldsymbol{y}-\boldsymbol{F}\left(\boldsymbol{x}_{\boldsymbol{i}}\right)\right]-\mathbf{S}_{a}^{-1}\left[\boldsymbol{x}_{\boldsymbol{i}}-\boldsymbol{x}_{\boldsymbol{a}}\right]\right\}
\end{aligned}
$$

where $\boldsymbol{F}$ is RFM modelled radiance.

The value of $\gamma$ is initialised to a small value of one. If the value obtained from the iteration reduces the error, the new estimate, $\boldsymbol{x}_{\boldsymbol{i}+\mathbf{1}}$, is accepted and $\gamma$ is divided by ten. If the error increases on $\boldsymbol{x}_{\boldsymbol{i}+\boldsymbol{1}}$ however, then $\gamma$ is multiplied by ten and Eq. 4 is solved again until an increment is obtained that
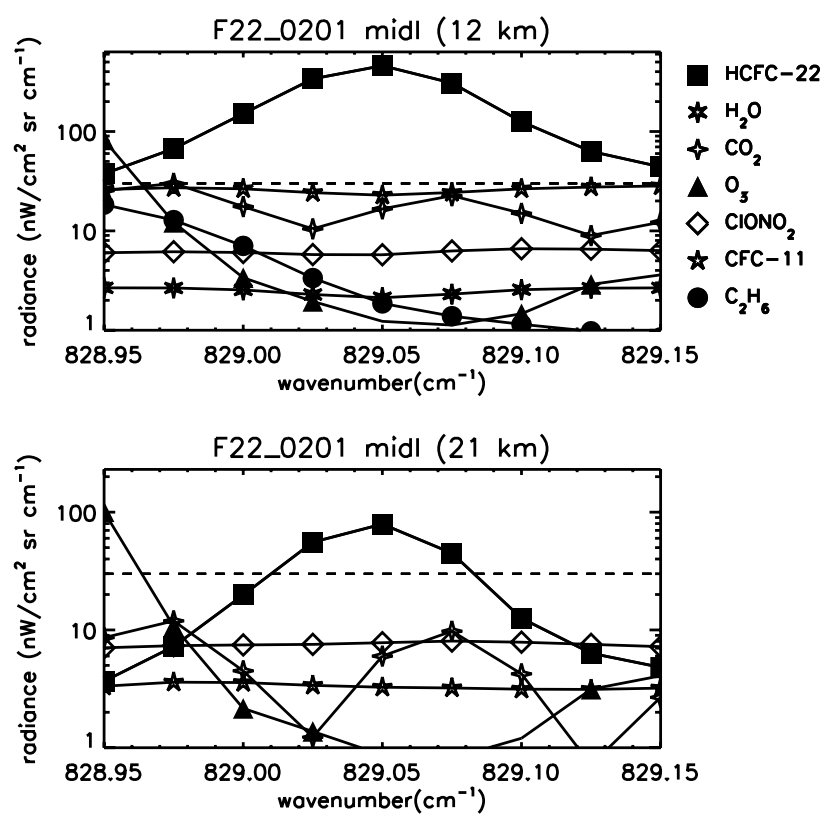

Fig. 1. Plot of modelled radiance contributions from the dominant radiatively active gases in the 828.95 to $829.15 \mathrm{~cm}^{-1}$ range in the mid-latitudes $\left(20\right.$ to $\left.65^{\circ}\right)$. The black dotted line represents a "typical" MIPAS-E in flight noise equivalent spectral radiance (NESR) of $30 \mathrm{nW} /\left(\mathrm{cm}^{2} \mathrm{sr} \mathrm{cm}^{-1}\right)$, for band A, based on the findings of Kleinert et al. (2007).

reduces the error. In our successful retrievals, the scheme converges within three to six iterations.

The OPERA performs a joint retrieval of HCFC-22 and total particle extinction on the same vertical grid as the measurements by calculating a mean spectral radiance at each altitude in two distinct regions: one sensitive to the target gas and the other to total particle extinction. This approach allows retrievals to be performed in the presence of thin cloud/aerosol in the upper troposphere. However, thicker clouds will still cause problems and so cloud flagging with a standard MIPAS-E technique was used. Clouds were detected using a simple ratio approach by computing a ratio between the mean radiance in the 788.2 to $796.25 \mathrm{~cm}^{-1}$ and 832.3 to $834.4 \mathrm{~cm}^{-1}$ spectral bands (Spang et al., 2004) with a threshold value of 1.8. If ratios below this value were found in a profile between 9 and $21 \mathrm{~km}$ the whole profile was flagged as cloudy, no retrieval performed on the scan and the scheme then analyzes the next scan. Pressure, temperature, water vapour, ozone and nitric acid vmrs, necessary in the forward model to compute both $\mathbf{K}$ and $\boldsymbol{F}$, were taken from offline level 2 products from the MIPAS-E processor (version 4.61). A priori HCFC-22 vmr information was taken from the version 3.1 climatology files of (Remedios et al., 2007) with an assumed uncertainty of $100 \%$ on the profile. Volume mixing ratio information for other contaminants in the target gas and total extinction microwindows 


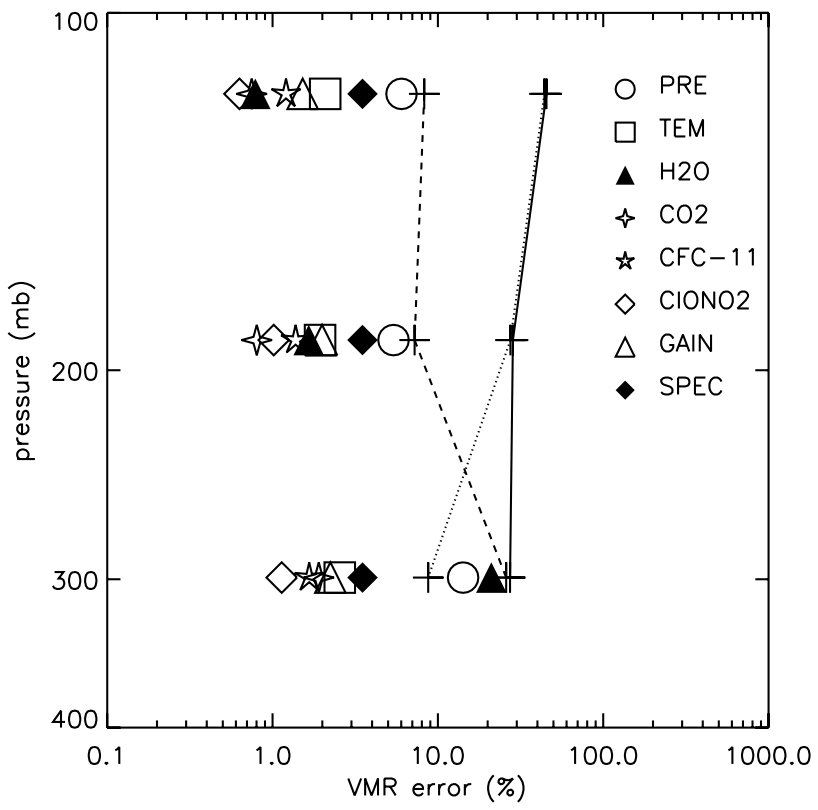

Fig. 2. Mean global error budget for HCFC-22 vmr retrievals. The solid black line represents the total error on a single retrieval. The random (dotted) and systematic (dashed) component of the error are also shown. Systematic errors are dominated by pressure ("PRE”), HCFC-22 spectroscopy ("SPEC"), gain, temperature ("TEM"), $\mathrm{ClONO}_{2}$ and $\mathrm{CFC}-11$ uncertainties.

also came from the version 3.1 climatology files of Remedios et al. (2007). Spectroscopic data were taken from HITRAN 2000 (Rothman et al., 2003).

\subsection{Retrieval errors}

A detailed HCFC-22 error analysis is shown in Fig. 2 (random, systematic and total errors). The random errors are comprised of retrieval noise and model parameter error. For the model parameter error, the one sigma uncertainties for pressure, temperature, water vapour and ozone were derived from an analysis of MIPAS-E level 2 data and applied for each gas. The one sigma uncertainties for the other contaminants were taken from the standard reference atmospheres of Remedios et al. (2007). The systematic model parameter errors were calculated using measured biases in MIPAS-E data. An uncertainty of $20 \%$ has been indicated for MIPASE water vapour (Lahoz et al., 2004), 10\% for ozone (Cortesi et al., 2007) and $15 \%$ for nitric acid (Wetzel et al., 2007). Uncertainties of $1 \mathrm{~K}$ for temperature (Ridolfi et al., 2007) and $4 \%$ for pressure (Raspollini et al., 2006) were used. Although a systematic bias in the atmosphere files for the other contaminants was expected to be small, we assumed a $10 \%$ uncertainty for each of them. The errors due to uncertainties in these gases were likely to be lower in the real measurements than calculated here. The uncertainty of the instru- ment gain and instrument offset were taken to be $2 \%$ and $2 \mathrm{nW} /\left(\mathrm{cm}^{2} \mathrm{sr} \mathrm{cm}^{-1}\right)$ respectively (Spang et al., 2005). Spectroscopic inaccuracies of HCFC-22 cross-section data were set to 3.5\% (Clerbaux et al., 1993). The total error on a single retrieved vmr was below $50 \%$ at pressures above $100 \mathrm{mb}$, and in the 'best case' better than 30\%. Systematic errors are dominated by the spectroscopic measurement uncertainties of HCFC-22 (3.5\%) propagating into the retrieved vmrs. The error contribution due to other gases in the microwindow was dominated by uncertainties in CFC- 11 .

\subsection{Retrieval characterization}

There are many ways to characterise the data quality of a single profile retrieval such as averaging kernels, information content and the degrees of freedom for signal (dfs) of the measurement (Rodgers, 2000). Figure 3 shows representative averaging kernels for a single mid-latitude profile of MIPAS-E data in 2003; HCFC-22 averaging kernels are strongly peaked above 0.4 in the upper troposphere and lowermost stratosphere. The area of each averaging kernel shown in Fig. 3 is close to unity, indicating that the retrieval results are nearly free of a priori influence. The width of an averaging kernel determines the vertical resolution of a measurement and is also used to ascertain the information content and degrees of freedom for a measurement. We find that the vertical resolution of the HCFC-22 observations are generally between 3 and $4 \mathrm{~km}$, although at pressures below $100 \mathrm{mb}$ the vertical resolution is between 5 and $6 \mathrm{~km}$. Between 50 and $300 \mathrm{mb}$ (approximately 9 to $21 \mathrm{~km}$ ) we generally observed between three and four degrees of freedom in the five MIPAS-E measurements in that height range; this information was highest at the summer pole (between 3.5 and 4) and lowest at the winter pole (between 2.5 and 3 ).

\subsection{Processing of OPERA data}

HCFC-22 retrievals were very sensitive to random error as there exists only nine spectral points in the 828.95 to $829.15 \mathrm{~cm}^{-1}$ microwindow. In the results section we have averaged profiles for the global mean and also by latitude band and as such the propagation of a priori information into the final result must be taken into account. A bias correction of up to $0.8 \%$ was applied for the a priori influence, following Burgess et al. (2004), where the measurement $(\hat{\boldsymbol{m}})$ of the true atmosphere can be determined using the a priori $\left(\boldsymbol{x}_{a}\right)$, the defined a priori variance $\left(\mathbf{S}_{a}\right)$, the retrieved $(\hat{\boldsymbol{x}})$ profiles and the retrieval error variance $\left(\mathbf{S}_{x}\right)$ information:

$\hat{\boldsymbol{m}}=\left(\hat{\boldsymbol{x}} / \mathbf{S}_{\boldsymbol{x}}\right)-\left(\boldsymbol{x}_{\boldsymbol{a}} / \mathbf{S}_{a}\right)\left(1 / \mathbf{S}_{x}-1 / \mathbf{S}_{a}\right)^{-1}$

\section{Results}

Although surface measurements of HCFC-22 vmrs are routinely performed [e.g. the ESRL surface network Montzka 


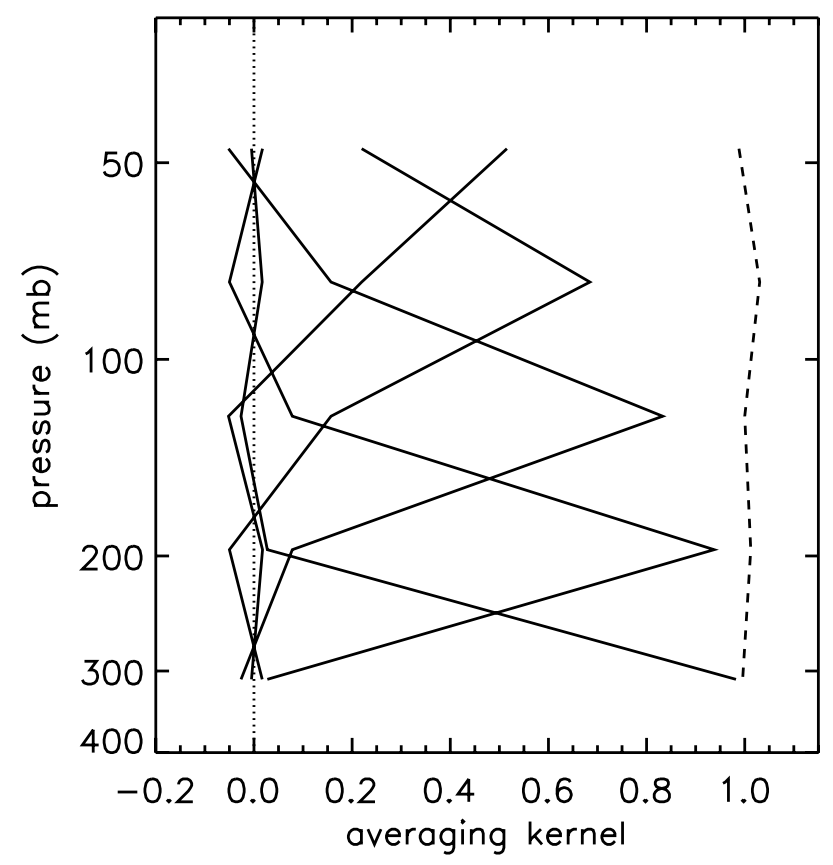

Fig. 3. Representative averaging kernels for a single mid-latitude HCFC-22 retrieval in 2003. The five measurement levels are at $310 \mathrm{mb}, 195 \mathrm{mb}, 125 \mathrm{mb}, 70 \mathrm{mb}$ and $40 \mathrm{mb}$, corresponding to the equivalent MIPAS-E nominal altitudes of 9, 12, 15, 18 and $21 \mathrm{~km}$. There are almost four degrees of freedom for these five measurements. The highest peaks are at higher pressures. The dashed black line represents the sum of the rows of the averaging kernel at each tangent pressure

et al., 1993], measurements of HCFC-22 vmrs in the upper troposphere and lower stratosphere are generally limited to infrequent balloon or aircraft measurement campaigns. Solar occultation limb measurements by ATMOS (Gunson et al., 1996) or more recently from ACE (Bernath et al., 2005) have provided valuable information on the vertical profile of HCFC-22 but global coverage is only achieved in these cases if many months of data are combined. The MIPAS-E has provided global limb measurements of the atmosphere since September 2002 albeit with interruptions due to ice decontamination and problems with the interferometer slides.

For this study we have retrieved HCFC-22 vmrs and total particle extinctions from one week of data from each season in 2003; these data were recorded at high spectral resolution $\left(0.025 \mathrm{~cm}^{-1}\right)$. Weeks were chosen that had very good data availability for both the measured level $1 \mathrm{~b}$ (calibrated and geolocated) spectra and offline (version 4.61 and 4.62) level 2 data for pressure, temperature, water vapor, nitric acid and ozone. Zonal mean profile results are shown from 8 to 14 January (2192 profiles), 15 to 21 April (1295 profiles), 8 to 14 July (711 profiles) and 15 to 21 October (2236 profiles).

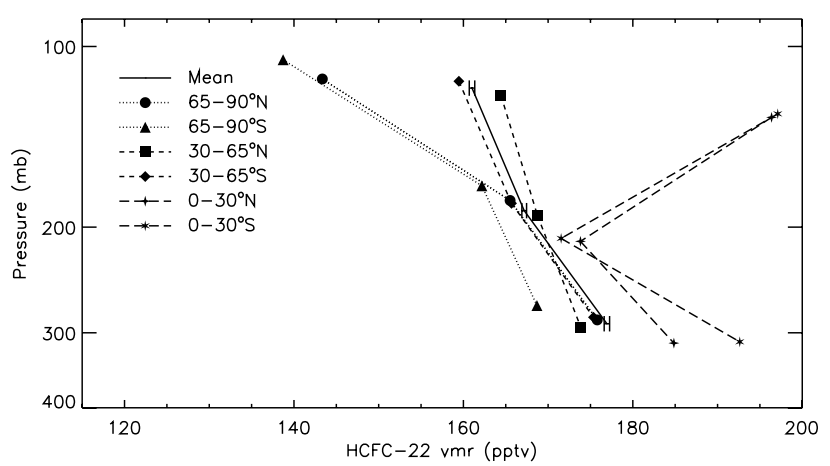

Fig. 4. HCFC-22 vmr retrievals from 6434 converged profiles from 2003. Means by latitude band are also shown.

\subsection{Zonal mean profiles}

The global mean profile from the 6434 converged profiles from 2003 is shown in Fig. 4. Although data were retrieved at five MIPAS-E measurement levels between 9 and $21 \mathrm{~km}$, we decided to restrict our analysis to data at heights where there is more information in the retrieval arising from the measurement than the a priori information by analysis of the Fisher information matrix described by Rodgers (2000), correcting for the remaining small a priori bias using a technique described in Sect. 2.4. The global mean data shown display both a tropospheric and stratospheric component; as HCFC22 is purely anthropogenic in origin the decrease in $\mathrm{vmr}$ with increasing altitude is due to increasing photolysis.

The global mean surface vmr of HCFC-22 for 2003 (derived from ESRL flask measurements) was $158 \mathrm{pptv}$. This compares quite well with our mean MIPAS-E vmr at $300 \mathrm{mb}$ of $177 \pm 17.5 \mathrm{pptv}$ where the error is the systematic uncertainty; the random error on the mean at $300 \mathrm{mb}$ was $0.5 \mathrm{pptv}$. It is important to note that our data are only slightly Northern Hemisphere (NH) biased (56\% of data points, 3590 profiles) compared to the Southern Hemisphere (SH) (2844 profiles). It has been shown by Waugh and Hall (2002) that there is an interhemispheric variation in gas concentrations with an anthropogenic source; interhemispheric transport takes around one year. For a gas such as HCFC-22, with an annual growth rate of $5 \mathrm{pptv} / \mathrm{yr}$, the mean $\mathrm{NH}$ tropospheric surface $\mathrm{HCFC}$ $22 \mathrm{vmr}$ in 2003 was $166 \mathrm{pptv}$ compared to $150 \mathrm{pptv}$ in the $\mathrm{SH}$ (based on ESRL flask measurements).

Due to the large number of retrieved data we also investigated latitudinal variability of HCFC- 22 with the results overlaid in Fig. 4. In particular, the polar data show good agreement in profile shape but at $300 \mathrm{mb}$ the Northern Polar mean was 8 pptv higher than the Antarctic mean. Mid-latitude data also showed good profile shape agreement with no systematic hemispheric differences; however, below the $200 \mathrm{mb}$ pressure level the mean NH HCFC-22 vmr is 5 pptv greater than in the SH. Finally the tropical data, although expected to be mostly tropospheric and therefore not 


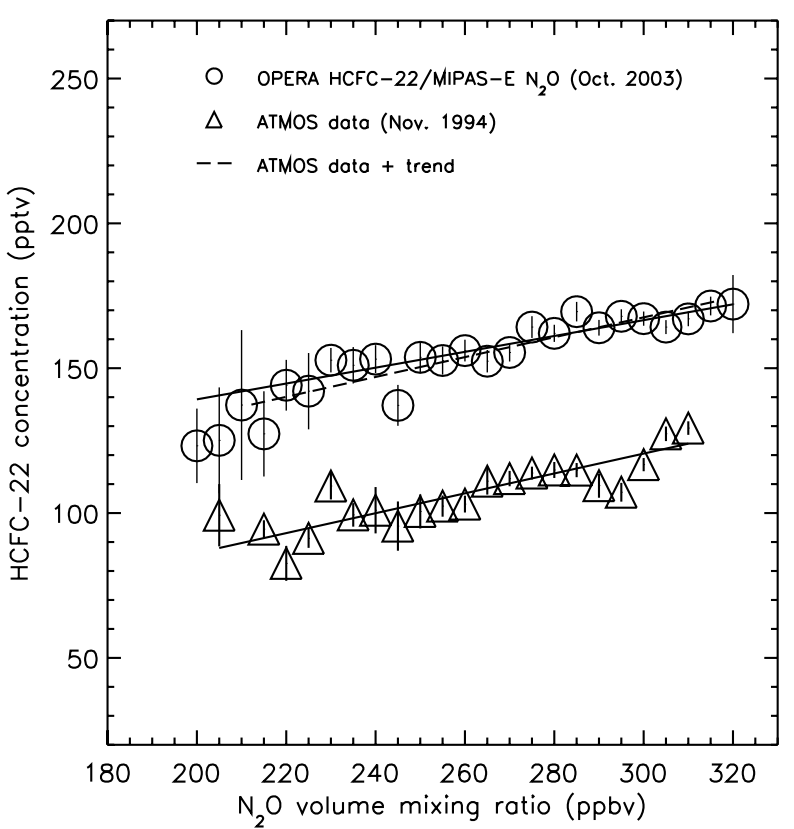

Fig. 5. ATMOS (AT-3, version 3 ) data and MIPAS-E data (version 4.61 for $\mathrm{N}_{2} \mathrm{O}$ ) between $20^{\circ} \mathrm{N}$ and $50^{\circ} \mathrm{N}$. Open triangles and open squares display averages in 5 ppbv $\mathrm{N}_{2} \mathrm{O}$ intervals. The one standard deviations of both the ATMOS and the OPERA derived HCFC-22 vmr data within each bin are also shown. The dashed black line represents the "expected" growth in both HCFC-22 and $\mathrm{N}_{2} \mathrm{O}$ since the ATMOS data in 1994 based on the observed trend in global average surface measurements made by ESRL since that time.

to show a decrease in HCFC-22 over the measured levels, does show some unexpectedly high HCFC -22 vmrs at approximately $150 \mathrm{mb}$ of over $195 \mathrm{pptv}$. The exact cause of this anomalously high HCFC-22 is most likely due to residual cloud contamination in the tropical UTLS spectra, not detected by our cloud detection ratio of 1.8. Greenhough et al. (2005) explored the use of the cloud index (CI) for cloudflagging MIPAS-E data and calculated that the CI threshold of 1.8 corresponds to effective extinctions of $5 \times 10^{-4}$ to $2 \times 10^{-3} \mathrm{~km}^{-1}$ at altitudes of 12 and $18 \mathrm{~km}$ respectively in the tropics. Although we use a low CI threshold of 1.8, these results show that it may be necessary to increase the CI threshold in the tropics, possibly up to a value of 4 , to flag all cloud-contaminated spectra in the tropical upper troposphere.

\subsection{Trend analysis}

As outlined in the introduction, the global surface vmr of HCFC-22 has been monitored since 1992, through the ESRL, with a near-linear rise of $5.2 \mathrm{pptv} / \mathrm{yr}$ measured between 1992 and January 2004. There have been several studies (e.g. Miller et al., 1998; O'Doherty et al., 2004; Irion et al., 1994; Rinsland et al., 2005b) to monitor the tropo- spheric growth rate of HCFC-22 from individual surface stations. Little is known, however, about the stratospheric growth rate of $\mathrm{HCFC}-22$.

We have calculated the average stratospheric growth rate of HCFC-22 by comparing target vmrs with $\mathrm{N}_{2} \mathrm{O}$ for both ATMOS (version 3 data; 3 to 14 November 1994) and MIPAS-E (version 4.61 data; 15 to 21 October 2003). Elkins et al. (2004) used NOAA/ESRL measurements of $\mathrm{N}_{2} \mathrm{O}$ vmrs to calculate a tropospheric 2003 global mean of 318 ppbv; therefore, we assume that where MIPAS-E $\mathrm{N}_{2} \mathrm{O}$ vmrs are less than $318 \mathrm{ppbv}$, the measurements are likely to be stratospheric. MIPAS-E $\mathrm{N}_{2} \mathrm{O}$ has a precision of $\pm 10 \%$ and shows a positive bias with respect to several types of correlative measurements in the UTLS at pressures greater than $100 \mathrm{mb}$ (Camy-Peyret et al., 2004). As such, we believe a 318 ppbv cut-off is conservative for this purpose but assign an error of $10 \%$ between 20 and $50^{\circ} \mathrm{N}$ and $5 \%$ between 60 and $80^{\circ} \mathrm{S}$ for MIPAS-E $\mathrm{N}_{2} \mathrm{O}$ based on a direct comparison of mean $\mathrm{N}_{2} \mathrm{O}$ with expected tropospheric values (R. Leigh, personal communication).

We report the average lower stratospheric growth rate of HCFC-22 between 1994 and 2003 for both the NH midlatitudes $\left(20^{\circ} \mathrm{N}\right.$ to $\left.50^{\circ} \mathrm{N}\right)$ and, for the first time, the $\mathrm{SH}$ polar region $\left(60^{\circ} \mathrm{S}\right.$ to $\left.80^{\circ} \mathrm{S}\right)$. Our analysis extends between 300 and $50 \mathrm{mb}$ for each region, a critical region in terms of climate study, where the vmr of HCFC-22 is expected to decrease with height (Fabian and Borchers, 2001). We restrict our analysis to data at heights where there is more information in the retrieval arising from the measurements than the a priori information by analysis of the Fisher information matrix described by Rodgers (2000). Note that we also correct for the remaining small a priori bias, using a technique described in Sect. 2.4.

Figure 5 compares ATMOS HCFC -22 and $\mathrm{N}_{2} \mathrm{O}$ data with MIPAS-E HCFC- 22 and $\mathrm{N}_{2} \mathrm{O}$ between $20^{\circ} \mathrm{N}$ to $50^{\circ} \mathrm{N}$. The HCFC -22 vmrs were binned by 5 ppbv $\mathrm{N}_{2} \mathrm{O}$ increments, averaged, the standard error of each bin determined and displayed in Fig. 5. A total of 941 MIPAS-E data points and 238 ATMOS data points of HCFC-22 have been included for this comparison. It has been calculated that the systematic errors dominate our HCFC-22 error estimate and are of the order of $5 \%$ for HCFC-22 from MIPAS-E in the mid-latitudes (50 to $300 \mathrm{mb}$ ). The version 3 ATMOS data for HCFC-22 have a quoted accuracy of $11 \%$ and for $\mathrm{N}_{2} \mathrm{O} 5 \%$ over the same pressure range (Abrams et al., 1996).

From these data, we have derived an average HCFC-22 growth rate of $5.4 \pm 0.7 \mathrm{pptv} / \mathrm{yr}(3.5 \pm 0.4 \% / \mathrm{yr})$ in the midlatitude stratosphere $\left(20\right.$ to $\left.50^{\circ} \mathrm{N}\right)$ between 1994 and 2003. Our measured percentage growth rate is slightly lower than the $3.92 \pm 2.08 \% / y r$ determined by Rinsland et al. (2005a) who compared stratospheric ATMOS-3 (1994) and ACE (2004) HCFC- 22 near $30^{\circ} \mathrm{N}$. Our comparisons for the midlatitudes are similar to $\mathrm{ACE}$ as they cover an equivalent range of altitudes. 
We also report, for the first time, a Southern Hemisphere growth rate of HCFC-22 in the lower stratosphere $\left(60^{\circ} \mathrm{S}\right.$ to $80^{\circ} \mathrm{S}$ ), Fig. 6 . Using the same technique as for the mid-latitude estimate and measurements over the same pressure range (420 MIPAS-E data, 286 ATMOS data), we estimated an average yearly growth rate in HCFC-22 of $6.0 \pm 0.7 \mathrm{pptv} / \mathrm{yr}(4.3 \pm 0.5 \%)$ between 1994 and 2003. Considering that the age of air at $20 \mathrm{~km}$ between 60 and $80^{\circ} \mathrm{S}$ is on average around 4.5 years (Andrews et al., 2001) our stratospheric growth rate is likely to be similar to the tropospheric trend between 1989 and 1998. A regular observation program of tropospheric HCFC-22 vmrs have been carried out at Cape Grim, Tasmania $\left(40^{\circ} \mathrm{S}, 144^{\circ} \mathrm{E}\right)$ since April 1978. Miller et al. (1998) report a SH tropospheric growth rate from this station in 1992 of $5.5 \pm 0.1 \mathrm{pptv} / \mathrm{yr}$, slightly lower than our 1994 to 2003 measurement. By mid-1996 however Miller et al. (1998) report an increase in the Cape Grim HCFC-22 trend to $6.0 \pm 0.1 \mathrm{pptv} / \mathrm{yr}$, more consistent with our measurements. Our SH growth rate is $0.6 \mathrm{pptv} / \mathrm{yr}$ greater than that we measured in the $\mathrm{NH}$, but the errors overlap.

The gradient of the fit to HCFC-22 and $\mathrm{N}_{2} \mathrm{O}$ shown in Figs. 5 and 6 is related to the chemical lifetime of both species. The basis of the Plumb and Ko (1992) approach to estimating the chemical lifetime relies on the fact that long-lived species in the stratosphere exhibit an "equilibrium slope" determined by a balance between photochemical changes and transport processes. As the local stratospheric lifetimes of $\mathrm{N}_{2} \mathrm{O}$ and HCFC-22 are longer than the timescale for horizontal transport, their correlation is compact (Figs. 5 and 6). The linear correlation obtained gives the ratio of their lifetimes via:

$\frac{\tau_{1}}{\tau_{2}} \cong \frac{d \sigma_{2}}{d \sigma_{1}} \frac{\sigma_{1}}{\sigma_{2}}$

where $\tau_{1}$ and $\tau_{2}$ are the lifetimes of gas 1 (here HCFC-22) and gas $2\left(\mathrm{~N}_{2} \mathrm{O}\right)$ respectively, $\sigma_{1}$ and $\sigma_{2}$ are the (mean) mixing ratios of HCFC-22 and $\mathrm{N}_{2} \mathrm{O}$ respectively and $d \sigma_{2} / d \sigma_{1}$ is the slope of the linear correlation. We have tested this theory related to reprocessed MIPAS-E $\mathrm{N}_{2} \mathrm{O}$ (version 4.61) and OPERA retrieved HCFC-22 from MIPAS-E 11b spectra (version 4.61) and have estimated a global average lifetime of HCFC-22 in the lowermost stratosphere. Assuming an atmospheric lifetime of $\mathrm{N}_{2} \mathrm{O}$ of 114 years (IPCC, 2007), using only stratospheric data $\left(\mathrm{N}_{2} \mathrm{O}\right.$ less than $\left.318 \mathrm{pptv}\right)$ at pressures between 50 and $300 \mathrm{mb}$, we calculate a NH midlatitude $\left(20\right.$ to $\left.50^{\circ} \mathrm{N}\right)$ stratospheric lifetime of HCFC-22 of $246 \pm 38$ years increasing to $274 \pm 34$ years in Antarctica (60 to $80^{\circ} \mathrm{S}$ ). The uncertainty on the lifetime is calculated from the standard error of the least square polynomial fit and the estimated accuracy of the MIPAS-E HCFC- 22 and $\mathrm{N}_{2} \mathrm{O}$ data. Within errors, the difference between these two estimates are not significant. Since, within the errors, the two results overlap, we infer a global stratospheric lifetime of approximately $260 \pm 25$ years. These two estimates of strato-

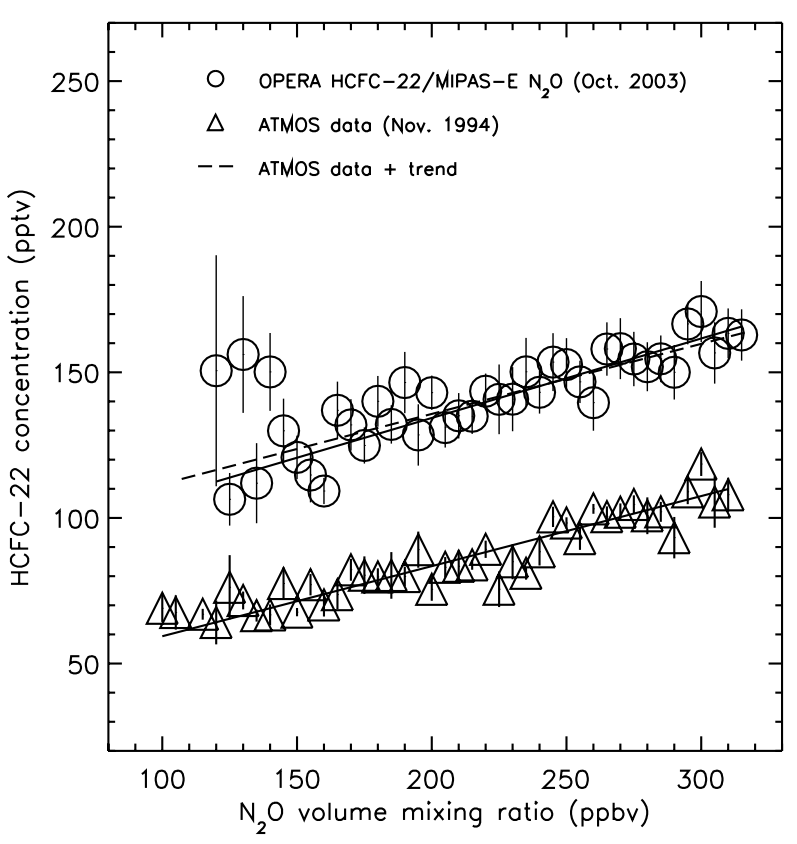

Fig. 6. ATMOS (AT-3, version 3) data and MIPAS-E data (version 4.61 for $\mathrm{N}_{2} \mathrm{O}$ ) between $60^{\circ} \mathrm{S}$ and $80^{\circ} \mathrm{S}$. Open triangles and open squares display averages in 5 ppbv $\mathrm{N}_{2} \mathrm{O}$ intervals. The one standard deviations of the OPERA derived HCFC-22 vmr data within each bin are also shown. The dashed black line represents the "expected" growth in both HCFC-22 and $\mathrm{N}_{2} \mathrm{O}$ since the ATMOS data in 1994 based on the observed trend in global average surface measurements made by ESRL since that time.

spheric HCFC-22 lifetime we derive are higher than the modeled global lifetimes derived by Avallone and Prather (1997) [205 years], Kanakidou et al. (1995) [214 years] and Spivakovsky et al. (2000) [229 years]. We therefore confirm that the stratospheric lifetime of HCFC-22 is significant and could be longer than previous estimates. Finally, the ratio of the HCFC-22 lifetime to that of $\mathrm{N}_{2} \mathrm{O}$ is between 2.2 (20 to $\left.50^{\circ} \mathrm{N}\right)$ and $2.4\left(60\right.$ to $\left.80^{\circ} \mathrm{S}\right)$.

\section{Conclusions}

HCFC-22 is both an important greenhouse gas (IPCC, 2007) and contributes to stratospheric ozone depletion (UNEP, 1996). Although a critical gas, previous stratospheric measurements have been limited to infrequent balloon campaigns or solar occultation missions which provide limited latitude coverage of data. Regular monitoring of the global lower stratospheric distribution of HCFC-22 is now feasible due to the advent of instruments such as the MIPAS-E measuring limb thermal emission.

This work has demonstrated the ability of the OPERA scheme to retrieve HCFC-22 vmrs from MIPAS-E spectral data between 9 and $21 \mathrm{~km}$. Based on an error evaluation, 
it is feasible to identify HCFC-22 in individual spectra and assign 3-4 degrees of freedom to the retrievals. Averaging single profiles from many orbits reduced the random errors considerably and the major error source arose from systematic errors; particularly inaccuracies in the HCFC22 spectroscopy used in the forward model. The yearly mean polar profile in 2003 shows distinct tropospheric $(173.1 \pm 10.9 \mathrm{pptv})$ and stratospheric $(141.6 \pm 7.7 \mathrm{pptv}) \mathrm{com}-$ ponents. The same is true of the yearly mean mid-latitude profile with tropospheric $(174.5 \pm 11.8 \mathrm{pptv})$ and lowermost stratosphere (162.2 $\pm 8.2 \mathrm{pptv})$ components.

We have shown that MIPAS-E data can be compared to another, independent, satellite dataset to infer lower stratospheric trends in HCFC-22 vmrs. By comparison to ATMOS (AT-3) version 3 data from November 1994 we have estimated a Northern Hemisphere (NH) mid-latitudes (20 to $\left.50^{\circ} \mathrm{N}\right) \mathrm{HCFC}-22$ growth rate HCFC -22 of $5.4 \pm 0.7 \mathrm{pptv} / \mathrm{yr}$ $(3.5 \pm 0.4 \% / y r)$ between 1994 and 2003; which compares well with the stratospheric $\mathrm{NH} 25$ to $35^{\circ} \mathrm{N}$ growth rate of $3.92 \pm 2.08 \% / y r$ estimated by Rinsland et al. (2005a) between 1994 and 2004.

We have also calculated, for the first time, a mean lower stratosphere HCFC-22 growth rate for the Southern Hemisphere $(\mathrm{SH})$ polar regions $\left(60\right.$ to $\left.80^{\circ} \mathrm{S}\right)$. Between 1994 and 2003, we measured an increase of $6.0 \pm 0.7 \mathrm{pptv} / \mathrm{yr}$ $(4.3 \pm 0.5 \% / \mathrm{yr})$. We also note that our SH rate of increase is just over $0.6 \mathrm{pptv} / \mathrm{yr}$ higher than our measured $\mathrm{NH}$ average.

We have tested the feasibility of using a global data set of remotely sensed MIPAS-E data to measure the lifetime of HCFC-22 in the lowermost stratosphere. We derive the stratospheric lifetime of HCFC-22 at two locations; 20 to $50^{\circ} \mathrm{S}$ ( $246 \pm 38$ years) and 60 to $80^{\circ} \mathrm{S}(274 \pm 34$ years). Since the two sets of error bars overlap, we note a global stratospheric lifetime of approximately $260 \pm 25$ years. These estimates are higher than global stratospheric lifetimes estimated by various chemistry models ( 205 to 229 years).

Our work confirms that current satellite systems are highly suitable for trend monitoring of HCFC-22 in the stratosphere. There remains a need to continue monitoring the stratosphere to verify that future reductions in atmospheric loading, in response to restrictions on HCFC-22 production in the Montreal Protocol, are realized. Future work will likely involve monitoring the stratospheric trend of HCFC22 from comparison of different years of MIPAS-E data, extending further the availability to monitor global trends. This work also suggests that the global capabilities of MIPAS$E$ data would allow identification of latitudinal stratospheric trends of trace gases with stronger variations of tropospheric growth rates.

Acknowledgements. D. Moore was supported by a research studentship from the Natural Environment Research Council. The authors wish to thank the European Space Agency for access to MIPAS data under CUTLSOM (AO-357). The authors would also like to thank the NOAA Earth System Research Laboratory
Halocarbons and other atmospheric trace species group for making HCFC-22 flask data publically available via their website (http://www.esrl.noaa.gov/gmd/hats/). We would also like to thank A. Dudhia for providing us with the Oxford reference forward model (RFM) used in this study.

Edited by: A. Richter

\section{References}

Abrams, M. C., Chang, A. C., Gunson, M. R., Abbas, M. M., Goldman, A., Irion, F. W., Michelson, H. A., Newchurch, M. J., Rinsland, C. P., Stiller, G. P., and Zander, R.: On the assessment and uncertainty of atmospheric trace gas burden measurements with high resolution infrared solar occultation spectra from space by the ATMOS experiment, Geophys. Res. Lett., 23, 17, 23372340, doi:10.1029/96GL01794, 1996.

AFEAS (Alternative Fluorocarbons Environmental Acceptability Study): Production, Sales and calculated emissions of Fluorocarbons through 2001, http://www.afeas.org, 2003.

Andrews, A. E., Boering, K. A., Daube, B. C., Wofsy, S. C., Loewenstein, M., Jost, H., Podolske, J. R., Webster, C. R., Herman, R. L., Scott, D. C., Flesch, G. J., Moyer, E. J., Elkins, J. W., Dutton, G. S., Hurst, D. F., Moore, F. L., Ray, E. A., Romashkin, P. A., and Strahan, S. E.: Mean ages of stratospheric air derived from in situ observations of $\mathrm{CO}_{2}$, $\mathrm{CH}_{4}$, and $\mathrm{N}_{2} \mathrm{O}$, J. Geophys. Res., 106(D23), 32 295-32 314, doi:10.1029/2001JD000465, 2001.

Avallone, L. and Prather, M.: Tracer-tracer correlations: Threedimensional model simulations and comparisons to observations, J. Geophys. Res., 102(D15), 19233-19246, 1997.

Bernath, P. F., McElroy, C. T., Abrams, M. C., Boone, C. D., Butler, M., Camy-Peyret, C., Carleer, M., Clerbaux, C., Coheur, P.-F., Colin, R., DeCola, P., Gilbert, K., Jennings, D. E., Llewellyn, E. J., Lowe, R. P., Mathieu, E., McConnell, J. C., McHugh, M., McLeod, S. D., Michaud, R., Midwinter, C., Nassar, R., Nichitiu, F., Nowlan, C., Rinsland, C. P., Rochon, Y. J., Rowlands, N., Semeniuk, K., Simon, P., Skelton, R., Sloan, J. J., Soucy, M.-A., Strong, K., Tremblay, P., Turnbull, D., Walker, K. A., Walkty, I., Wardle, D. A., Wehrle, V., Zander, R., and Zou, J.: Atmospheric Chemistry Experiment (ACE): Mission overview, Geophys. Res. Lett., 32, L15S01, doi:10.1029/2005GL022386, 2005.

Brasseur G.: Atmospheric Chemistry and Global Change, Oxford University Press, Oxford, 298-299, New York, 1999.

Burgess, A. B., Grainger, R. G., Dudhia, A., and Payne V. H.: MIPAS measurements of sulphur hexafluoride $\left(\mathrm{SF}_{6}\right)$, Geophys. Res. Lett., 31, L05112, doi:10.1029/2003GL019143, 2004.

Camy-Peyret, C., Dufour, G., Payan, S., Oelhaf, H., Wetzel, G., Stiller, G. P., Blumenstock, T., Blom, C. E., Gulde, T., Glatthor, N., Engel, A., Pirre, M., Catoire, V., Moreau, G., De Maziere, M., Vigouroux, C., Mathieu, E., Cortesi, U., and Mencaraglia F.: Validation of MIPAS $\mathrm{N}_{2} \mathrm{O}$ profiles by stratospheric balloon, aircraft and ground based measurements, Proceedings of the ACVE-2 meeting, 3-7 May, Frascati, Italy, 2004.

Clerbaux, C., Colin, R., Simon, P., and Granier C.: Infrared crosssections and global warming potentials of 10 alternative hydrohalocarbons, J. Geophys. Res., 98, 10 491-10 497, 1993. 
Cortesi, U., Lambert, J. C., De Clercq, C., Bianchini, G., Blumenstock, T., Bracher, A., Castelli, E., Catoire, V., Chance, K. V., De Mazire, M., Demoulin, P., Godin-Beekmann, S., Jones, N., Jucks, K., Keim, C., Kerzenmacher, T., Kuellmann, H., Kuttippurath, J., Iarlori, M., Liu, G. Y., Liu, Y., McDermid, I. S., Meijer, Y. J., Mencaraglia, F., Mikuteit, S., Oelhaf, H., Piccolo, C., Pirre, M., Raspollini, P., Ravegnani, F., Reburn, W. J., Redaelli, G., Remedios, J. J., Sembhi, H., Smale, D., Steck, T., Taddei, A., Varotsos, C., Vigouroux, C., Waterfall, A., Wetzel, G., and Wood, S.: Geophysical validation of MIPAS-ENVISAT operational ozone data, Atmos. Chem. Phys., 7, 4807-4867, 2007, http://www.atmos-chem-phys.net/7/4807/2007/.

Edwards, D. P.: GENLN2: A general line-by-line atmospheric transmittance and radiance model, Version 3.0 description and users guide, NCAR/TN-367-STR, National Center for Atmospheric Research, Boulder, Co, 1992.

Elkins, J. W., Dutton, G. S., Hall, B. D., Butler, J. H., Thompson, T. M., Mondeel, D. J., and Dlugokencky, E. J.: Global trends and distributions of atmospheric nitrous oxide, Eos Trans. AGU, 85(47), Fall Meet. Suppl., Abstract A51C-0779, 2004.

Fabian, P. and Borchers, R.: Growth of Halocarbon Abundances in the Stratosphere between 1977 and 1999, Adv. Space. Res., 28, No. 7, 961-964, 2001.

Fischer, H. and Oelhaf, H.: Remote sensing of vertical profiles of atmospheric trace constituents with MIPAS limb-emission spectrometers, Appl. Optics, 35, 2787-2796, 1996.

Fischer, H., Birk, M., Blom, C., Carli, B., Carlotti, M., von Clarmann, T., Delbouille, L., Dudhia, A., Ehhalt, D., Endemann, M., Flaud, J. M., Gessner, R., Kleinert, A., Koopmann, R., Langen, J., López-Puertas, M., Mosner, P., Nett, H., Oelhaf, H., Perron, G., Remedios, J., Ridolfi, M., Stiller, G., and Zander, R.: MIPAS: an instrument for atmospheric and climate research, Atmos. Chem. Phys. Discuss., 7, 8795-8893, 2007,

http://www.atmos-chem-phys-discuss.net/7/8795/2007/.

Forster, P., Ramaswamy, V., Artaxo, P., Bernsten, T., Betts, R., Fahey, D. W., Haywood, J., Lean, J., Lowe, D. C., Myrhe, G., Nganga, J., Prinn, R., Raga, G., Schulz, M., and van Dorland, R.: Changes in Atmospheric Constituents and in Radiative Forcing, in: Climate Change 2007: The Physical Basis. Contribution of Working Group I to the Fourth Assessment Report of the Intergovernmental Panel on Climate Change, edited by: Solomon, S., Qin, D., Manning, M., Chen, Z., Marquis, M., Averyt, K. B., Tignor, M., and Miller, H. L., Cambridge University Press, Cambridge, United Kingdom and New York, NY, USA, 2007.

Greenhough, J., Remedios, J. J., Sembhi, H., and Kramer, L. J.: Towards cloud detection and cloud frequency distributions from MIPAS infra-red observations, Adv. Space. Res., 36, 800-806, 2005.

Gunson, M. R., Abbas, M. M., Abrams, M. C., Allen, M., Brown, L. R., Brown, T. L., Chang, A. Y., Goldman, A., Irion, F. W., Lowes, L. L., Mahieu, E., Manney, G. L., Michelsen, H. A., Newchurch, M. J., Rinsland, C. P., Salawitch, R. J., Stiller, G. P., Toon, G. C., Yung, Y. L., and Zander R.: The Atmospheric Trace Molecule Spectroscopy (ATMOS) experiment: Deployment on the ATLAS Space Shuttle missions, Geophys. Res. Lett., 23, 2333-2336, doi:10.1029/96GL01569, 1996.

Intergovernmental Panel on Climate Change (IPCC): Climate Change 2001: The Scientific Basis, Contribution of Working Group I to the Third Assessment Report of the Intergovernmen- tal Panel on Climate Change, edited by J. T. Houghton et al., pp. 944, Cambridge University Press, UK, 2001.

Irion, F. W., Brown, M., Toon, G., and Gunson, M. R.: Increase in Atmospheric $\mathrm{CHF}_{2} \mathrm{Cl}$ (HCFC-22) over Southern California from 1985 to 1990, Geophys. Res. Lett., 21, 16, 1723-1726, 1994.

Kanakidou, M., Dentener, F., and Crutzen, P.: A global threedimensional study of the fate of HCFCs and HFC-134a in the troposphere, J. Geophys. Res., 100(D9),18 781-18 802, doi:10.1029/95JD01919, 1995.

Kleinert, A., Aubertin, G., Perron, G., Birk, M., Wagner, G., Hase, F., Nett, H., and Poulin, R.: MIPAS Level 1B algorithms overview: operational processing and characterization, Atmos. Chem. Phys., 7, 1395-1406, 2007, http://www.atmos-chem-phys.net/7/1395/2007/.

Lahoz, W., Geer, A., Swinbank, R., Jackson, D., Thornton, H., Dethof, A., and Fonteyn, D.: Modelling and assimilation: evaluation of MIPAS water vapour, Proceedings of the ACVE-2 meeting, 3-7 May, Frascati, Italy, 2004.

Miller, B. R., Huang, J., Weiss, R. F., Prinn, R. G., and Fraser, P. J. : Atmospheric trend and lifetime of chlorodifluoromethane (HCFC-22) and the global tropospheric $\mathrm{OH}$ concentration, J. Geophys. Res., 103(D11), 13 237-13 248, doi:10.1029/98JD00771, 1998.

Molina, M. J. and Rowland, F. S.: Stratospheric sink for chlorofluoromethanes-chlorine atom catalyzed destruction of ozone, Nature, 249, 810-812, 1974.

Montzka, S. A. and Fraser, P. J.: Controlled substances and other source gases, Chapter 1 in Scientific Assessment of Ozone Depletion: 2002, World Meteorological Organization Global Ozone Research and Monitoring Project, Report No. 47, 1.1-1.83, WMO, Geneva, Switzerland, 2003.

Montzka, S. A., Myers, R. C., Butler, J. H., and Elkins, J. W.: Global tropopsheric distribution and calibration scale of HCFC-22, Geophys. Res. Lett, 20, 8, 703-706, doi:10.1029/93GL00573, 1993.

Moore, D. P.: Measurements of HCFC-22 in the upper troposphere and lower stratosphere from the MIPAS-E instrument, $\mathrm{PhD}$ thesis, University of Leicester, 2005.

Moore, D. P., Waterfall, A. M., and Remedios, J. J.: The potential for radiometric retrievals of halocarbon concentrations from the MIPAS-E instrument, Adv. Space. Res., 37, 2238-2246, doi:10.1016/j.asr.2005.06.058, 2006.

O’Doherty, S., Cunnold, D. M., Manning, A., Miller, B. R., Wang, R. H. J., Krummel, P. B., Fraser, P. J., Simmonds, P. G., McCulloch, A., Weiss, R. F., Salameh, P., Porter, L. W., Prinn, R. G., Huang, J., Sturrock, G., Ryall, D., Derwent, R. G., and Montzka S. A.: Rapid growth of hydrofluorocarbon 134a and hydrochlorofluorocarbons 141b, 142b, and 22 from Advanced Global Atmospheric Gases Experiment (AGAGE) observations at Cape Grim, Tasmania, and Mace Head, Ireland, J. Geophys. Res., 109, D06310, doi:10.1029/2003JD004277, 2004.

Plumb, R. A. and Ko, M. K. W.: Interrelationships between mixing ratios of long-lived stratospheric constituents, J. Geophys. Res., 97, 10 145-10 156, doi:10.1029/92JD00450, 1992.

Raspollini, P., Belotti, C., Burgess, A., Carli, B., Carlotti, M., Ceccherini, S., Dinelli, B. M., Dudhia, A., Flaud, J. M., Funke, B., Höpfner, M., López-Puertas, M., Payne, V., Piccolo, C., Remedios, J. J., Ridolfi, M., and Spang, R.: MIPAS level 2 operational 
analysis, Atmos. Chem. Phys., 6, 5605-5630, 2006, http://www.atmos-chem-phys.net/6/5605/2006/.

Remedios, J. J., Leigh, R. J., Waterfall, A. M., Moore, D. P., Sembhi, H., Parkes, I., Greenhough, J., Chipperfield, M. P., and Hauglustaine, D.: MIPAS reference atmospheres and comparisons to V4.61/V4.62 MIPAS level 2 geophysical data sets, Atmos. Chem. Phys. Discuss., 7, 9973-10 017, 2007.

Ridolfi, M., Blum, U., Carli, B., Catoire, V., Ceccherini, S., Claude, H., De Clercq, C., Fricke, K. H., Friedl-Vallon, F., Iarlori, M., Keckhut, P., Kerridge, B., Lambert, J.-C., Meijer, Y. J., Mona, L., Oelhaf, H., Pappalardo, G., Pirre, M., Rizi, V., Robert, C., Swart, D., von Clarmann, T., Waterfall, A., and Wetzel, G.: Geophysical validation of temperature retrieved by the ESA processor from MIPAS/ENVISAT atmospheric limb-emission measurements, Atmos. Chem. Phys., 7, 4459-4487, 2007, http://www.atmos-chem-phys.net/7/4459/2007/.

Rinsland, C. P., Boone, C., Nassar, R., Walker, K., Bernath, P., Mahieu, E., Zander, R., McConnell, J. C. and Chiou, L.: Trends of $\mathrm{HF}, \mathrm{HCl}, \mathrm{CCl}_{2} \mathrm{~F}_{2}, \mathrm{CCl}_{3} \mathrm{~F}, \mathrm{CHClF}_{2}$ (HCFC-22), and $\mathrm{SF}_{6}$ in the lower stratosphere from Atmospheric Chemistry Experiment (ACE) and Atmospheric Trace Molecule Spectroscopy (ATMOS) measurements near $30^{\circ} \mathrm{N}$ latitude, Geophys. Res. Lett., 32, L16S03, doi:10.1029/2005GL022415, 2005a.

Rinsland, C. P., Chiou, L. S., Goldman, A., and Wood, S. W.: Long-term trends in $\mathrm{CHF}_{2} \mathrm{Cl}$ (HCFC-22) from high spectral resolution infrared solar absorption measurements and comparison with in situ measurements, J. Quant. Spectrosc. Ra., 90, 367375, 2005b.

Rodgers, C. D.: Inverse methods for atmospheric sounding, vol. 2 of Series on Atmospheric, Oceanic and Planetary Physics, World Scientific, 2000.

Rothman, L. S., Barbe, A., Benner, D. C., Brown, L. R., CamyPeyret, C., Carleer, M. R., Chance, K., Clerbaux, C., Dana, V., Devi, V. M., Fayth, A. Flaud, J. M., Gamache, R. R., Goldman, A., Jacquemart, D., Jucks, K. W., Lafferty, W. J., Mandin, J.-Y., Massie, S. T., Nemtchinov, V., Newnham, D. A., Perrin, A., Rinsland, C. P., Schroeder, J., Smith, K. M., Smith, M. A. H., Tang, K., Toth, R. A., Vander Auwera, J., Varanasi, P., and Yoshino, K.: The HITRAN molecular spectroscopic database: edition of 2000 including updates through 2001, J. Quant. Spectrosc. Ra., 82(1-4), 5-44, 2003.

Sihra, K., Hurley, M. D., Shine, K. P., and Wallington, T. J.: Updated radiative forcing estimates of sixty-five, halocarbons and non-methane hydrocarbons, J. Geophys. Res., 106, D17, 20493 20 506, doi:10.1029/2000JD900716, 2001.
Spang, R., Remedios, J. J., Kramer, L. J., Poole, L. R., Fromm, M. D., Müller, M., Aumgarten, G., and Konopka, P.: Polar stratospheric cloud observations by MIPAS on ENVISAT: detection method, validation and analysis of the northern hemisphere winter 2002/2003, Atmos. Chem. Phys., 5, 679-692, 2005, http://www.atmos-chem-phys.net/5/679/2005/.

Spang, R., Remedios, J. J., and Barkley, M. P.: Colour indices for the detection and differentiation of cloud types in infrared limb emission spectra, Adv. Space. Res., 33, 1041-1047, 2004.

Spivakovsky, C. M., Logan, J. A., Montzka, S. A., Balkanski, Y. J. Foreman-Fowler, M., Jones, D. B. A., Horowitz, L. W., Fusco, A. C., Brenninkmeijer, C. A. M., Prather, M. J., Wofsy, S. C., and McElroy, M. B.: Three-dimensional climatological distribution of tropospheric OH: Update and evaluation, J. Geophys. Res., 105, D7, 8931-8980, doi:10.1029/1999JD901006, 2000.

United Nations Environment Programme (UNEP): Handbook for the International Treaties for the Protection of the Ozone Layer, 6th ed., Ozone Secr., Nairobi, 35-66, 2003.

Varanasi, P.: Absorption spectra of HCFC-22 around $829 \mathrm{~cm}^{-1}$ at atmospheric conditions, J. Quant. Spectrosc. Ra., 48, 205-219, 1992.

Waugh, D. W. and Hall, T. M.: Age of stratospheric air: Theory, observations, and models, Rev. Geophys., 40, 1010, doi:10.1029/2000RG000101, 2002.

Wetzel, G., Bracher, A., Funke, B., Goutail, F., Hendrick, F., Lambert, J.-C., Mikuteit, S., Piccolo, C., Pirre, M., Bazureau, A., Belotti, C., Blumenstock, T., De Mazire, M., Fischer, H., Huret, N., Ionov, D., Lpez-Puertas, M., Maucher, G., Oelhaf, H., Pommereau, J.-P., Ruhnke, R., Sinnhuber, M., Stiller, G., van Roozendael, M., and Zhang, G.: Validation of MIPAS-ENVISAT NO2 operational data, Atmos. Chem. Phys., 7, 3261-3284, 2007, http://www.atmos-chem-phys.net/7/3261/2007/.

WMO: Scientific Assessment of Ozone Depletion: 1994, Global Ozone Research Project-Report No. 37, Geneva, Switzerland, 1995.

WMO: Scientific assessment of ozone depletion: 2006, Global Ozone Research and Monitoring Project-Report No. 50, Geneva, Switzerland, 2007. 